\title{
Linkages between southern hemisphere westerlies and hydrological changes in semi-arid Patagonia during the last 16,000 years
}

Torsten Haberzettr ${ }^{1}$, C. MAYR ${ }^{2,3}$, M. Wille ${ }^{4}$ and B. ZolitschKa ${ }^{5}$

'Sedimentology and Environmental Geology, Geoscience Center, University of Göttingen, Germany; Torsten.Haberzettl@geo.uni-goettingen.de; ${ }^{2}$ GeoBio-CenterLMU, University of Munich, Germany; Institute of Chemistry and Dynamics of the Geosphere, Research Center Jülich, Germany; ${ }^{4}$ Seminar for Geography and Education, University of Cologne, Germany; ${ }^{5}$ Geomorphology and Polar Research, Institute of Geography, University of Bremen, Germany

Sediment cores from the 100-m-deep maar lake Laguna Potrok Aike $\left(52^{\circ} \mathrm{S}, 113 \mathrm{~m}\right.$ asl, diameter $3.5 \mathrm{~km}$, Fig. 1) demonstrate that this lake provides a unique record of paleoenvironmental variability. It is located in the dry steppe of southern Patagonia (ca. $200 \mathrm{~mm}$ annual precipitation), an area with hitherto scarce paleoenvironmental information. Amongst other proxies, titanium (Ti) and total inorganic carbon (TIC) were identified to reflect hydrological changes (Haberzettl et al., 2005). Precipitating preferentially during lake level recessions and low stands, TIC can be used as an indicator of the evaporation-inflow-ratio and hence as a lake level proxy. $\mathrm{Ti}$ is a measure of fluvial input (minerogenic matter) and strongly related to precipitation. Comparing the sedimentary proxy records of Laguna Potrok Aike to radiocarbon-dated lake levels from seismic data demonstrated a close correlation. This is especially evident for the Little Ice Age, the Medieval Climate Anomaly and the Mid-Holocene Optimum (Haberzettl et al., 2005, 2007, in press). Here, we present a new compilation for the long sediment record from the center of the lake (Fig. 1) to demonstrate that west wind variability played a major role in hydrological changes within Patagonia over the last $16 \mathrm{kyr}$.

\section{Hydrological variations and west wind variability}

Interpreting low TIC concentrations during the late glacial as an indication of low ionic concentrations and primary productivity, the lake level of Laguna Potrok Aike was high from 16-13.2 cal kyr BP (Fig. 2). Yet, low values for Ti seem to contradict this proposal of a humid late glacial in this region. However, increased organic matter deposition and preservation (represented by total organic carbon (TOC) Fig. 2) during that period probably diluted the minerogenic sediment fraction. From 13.2-11.4 cal kyr BP the lake level was lower. The occurrence of the green alga Phacotus lenticularis between 12.8 and $11.4 \mathrm{cal} \mathrm{kyr}$ BP suggests also that surface water temperatures were warmer during this lowstand (Schlegel et al., 2000). The occurrence of Phacotus is approximately contemporary

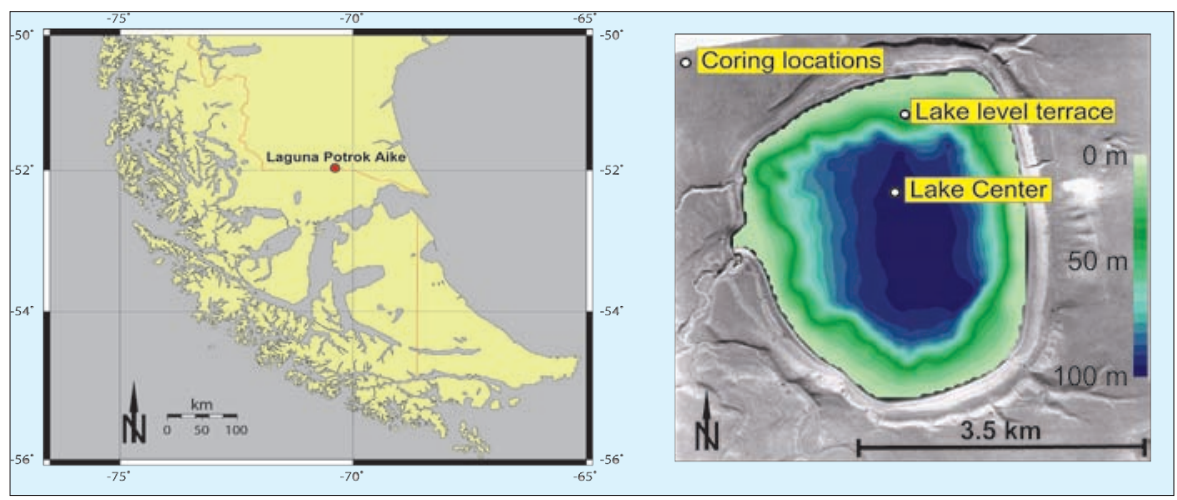

Figure 1: Research area and bathymetry of Laguna Potrok Aike with positions of sediment cores.

to the northern hemisphere Younger Dryas chronozone. Thereafter, TIC-inferred lake levels rose again and remained high until 8.65 cal kyr BP (Fig. 2). At this time drastic hydrological changes occurred at Laguna Potrok Aike. The lake receded to the hitherto lowest known level ca. $30 \mathrm{~m}$ below the present surface, creating a lake-level terrace with a seismically detected and radiocarbon-dated unconformity (Haberzettl et al., in press). A sediment core taken from that terrace (Fig. 1) showed undisturbed and continuous sedimentation from 6.75 cal kyr BP onward, manifesting a lake level rise. After $6.75 \mathrm{cal}$ kyr BP, proxies imply that the lake level varied in response to an alternation of humid and dry periods, but never dropped to the former lake level low stand of $-30 \mathrm{~m}$. The last humid period, ascribed to the Little Ice Age, appeared to have been the temporally most extended humid period since the early Holocene lake-level highstands prior to 8.65 cal kyr BP (Fig. 2, Haberzettl et al., 2007).

The hydrological variability during the Holocene can at least partially be ascribed to variations in the intensity of the southern hemisphere westerlies (Mayr et al., 2007; Wille et al., 2007). Changes in west wind intensity are documented in the sediment record of Laguna Potrok Aike by variable pollen input of Andean forest taxa (AFT), which consist mainly of pollen from the southern beech (Nothofagus). Pollen is transported by westerly winds from the moister Andean forest habitats to the semi-arid steppe region around Laguna Potrok Aike (Wille et al., 2007). Low tree pollen concentrations during the late glacial are probably due to the lack of ex- tensive forests. Hence, the Holocene pollen record (i.e., since ca. $11.6 \mathrm{cal}$ kyr BP, Fig. 2) mainly reflects changes in the intensity of westerly winds, a feature consistent with the interpretation of pollen records further to the west (Mayr et al., 2007). The coincidence of generally higher TIC concentrations, low Ti values and an increased input of AFT to the sediments since $8.65 \mathrm{cal} \mathrm{kyr}$ BP (Fig. 2), implies that the regional climate pattern with strong west winds that persists until today was established during the early Holocene.

\section{Outlook}

Four seismic surveys at Laguna Potrok Aike indicate ca. $400 \mathrm{~m}$ of undisturbed lacustrine sediments. This sediment archive will be drilled in the framework of the ICDP project PASADO (cf., PAGES News 14(2): 39-40) in 2008. The site promises a long continental environmental and climatic record since formation of the maar ca. 770 kyr ago, with decadal-to-centennial resolution. Obtained data and climate-hydrology linkages will serve as a key for a better understanding of late- to mid-Pleistocene climate conditions in southern South America, especially if compared to marine and ice core records. Until now, such long high-resolution terrestrial records are still lacking from the mid- to high latitudes of the southern hemisphere.

\section{Acknowledgments}

We thank all members of the project SALSA for their cooperation. The German Federal Ministry of Education and Science financially supported our research in the framework of the Climate Research Program DEKLIM (grants 01 LD 0034 and 0035). 


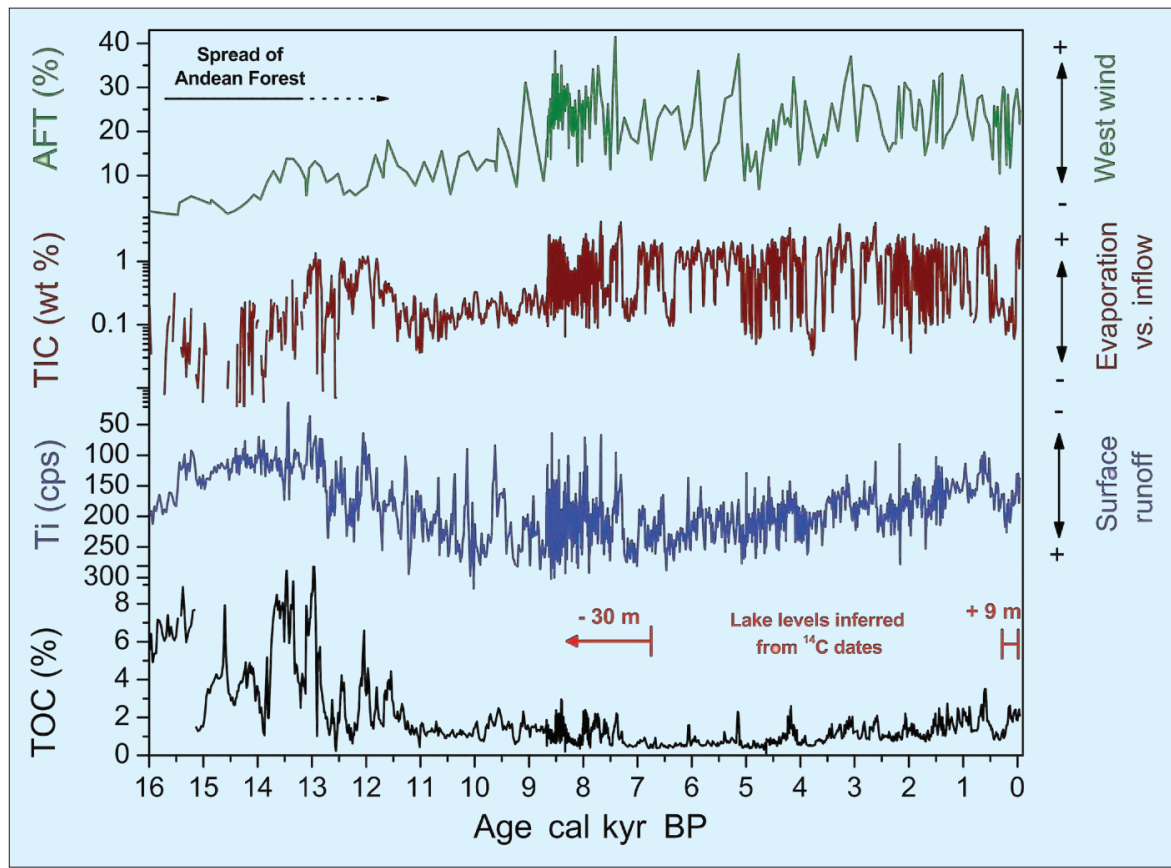

Figure 2: Climate proxies of the Laguna Potrok Aike sediment archive: Pollen of Andean Forest Taxa (AFT) as a measure of west wind variability, total inorganic carbon (TIC) as a proxy of the balance between evaporating and inflowing waters, and titanium content (Ti; given as counts per second-cps) representing minerogenic sedimentary input mainly by surface runoff. Note that Ti and AFT are influenced by other effects in the late glacial. Radiocarbondated lake levels relative to today are given by red bars. Total organic carbon (TOC) is plotted to demonstrate that there might be a dilution of Ti by organic matter during the late glacial.

\section{References:}

Haberzettl, T., Fey, M., Lücke, A., Maidana, N.I., Mayr, C., Ohlendorf, C, Schäbitz, F., Schleser, G.H., Wille, M. and Zolitschka, B., 2005: Climatically induced lake level changes during the last two millennia as reflected in sediments of Laguna Potrok Aike, southern Patagonia (Santa Cruz, Argentina), Journal of Paleolimnology, 33: 283-302.

Haberzettl, T., Corbella, H. Fey, M. Janssen, S. Lücke, A. Mayr, A Ohlendorf, C., Schäbitz, F., Schleser, G.H., Wille, M., Wulf, S. and Zolitschka, B., 2007: Lateglacial and Holocene wet-dry cycles in southern Patagonia: chronology, sedimentology and geochemistry of a lacustrine record from Laguna Potrok Aike, Argentina, The Holocene, 17(3): 297-311.

Haberzettl, T., Kück, B., Wulf, S., Anselmetti, F., Ariztegui, D., Corbella, H., Fey, M., Janssen, S., Lücke, A., Mayr, C., Ohlendorf, C., Schäbitz, F., Schleser, G.H., Wille, M. and Zolitschka, B., in press: Hydrological variability in southeastern Patagonia and explosive volcanic activity in the southern Andean Cordillera during Oxygen Isotope Stage 3 and the Holocene inferred from lake sediments of Laguna Potrok Aike, Argentina, Palaeogeography, Palaeoclimatology, Palaeoecology.

Mayr, C., Wille, M., Haberzettl, T., Fey, M., Janssen, S., Lücke, A., Ohlendorf, C., Oliva, G., Schäbitz, F., Schleser, G.H. and Zolitschka, B., 2007: Holocene variability of the Southern Hemisphere westerlies in Argentinean Patagonia $\left(52^{\circ} \mathrm{S}\right)$, Quaternary Science Reviews, 26: 579-584.

Wille, M., Maidana, N.I., Schäbitz, F., Fey, M., Haberzettl, T., Janssen, S Lücke, A., Mayr, C., Ohlendorf, C., Schleser, G.H. and Zolitschka, B., 2007: Vegetation and climate dynamics in southern South America: The microfossil record of Laguna Potrok Aike, Santa Cruz, Argentina, Review of Palaeobotany and Palynology, 146 234-246

\section{Tree-ring evidence for tropical-extratropical influences on climate variability along the Andes in South America} Ricardo Villalba

Departamento de Dendrocronología e Historia Ambiental, IANIGLA, Mendoza, Argentina; ricardo@lab.cricyt.edu.ar

Instrumental records show that the climate system is characterized by low- and high-latitude modes of variability, which fluctuate at many different temporal scales. The best known is the El NiñoSouthern Oscillation (ENSO) phenomenon in the tropical Pacific, which dominates global climate variations on interannual timescales mostly ranging from 3 to 6 years (Diaz and Markgraf, 2000). The Antarctic Oscillation (AAO) is the dominant mode of climate variability at mid- to high latitudes in the southern hemisphere (Thompson and Wallace, 2000). The positive state of this annular mode is associated with intensified subtropical highs and strong polar lows, which drive a strong extratropical circulation. Interannual-todecadal variability of climate associated with these atmospheric circulation modes exhibits large spatial and temporal variance that remains poorly documented. Continental- and hemispheric-scale networks of instrumental and proxy climate data are needed to document and help understand these changes in the oceanatmosphere system.

Tree rings represent the most broadly distributed, annually-resolved source of proxy climate data throughout the Andes Cordillera and, thereby, supply the base-

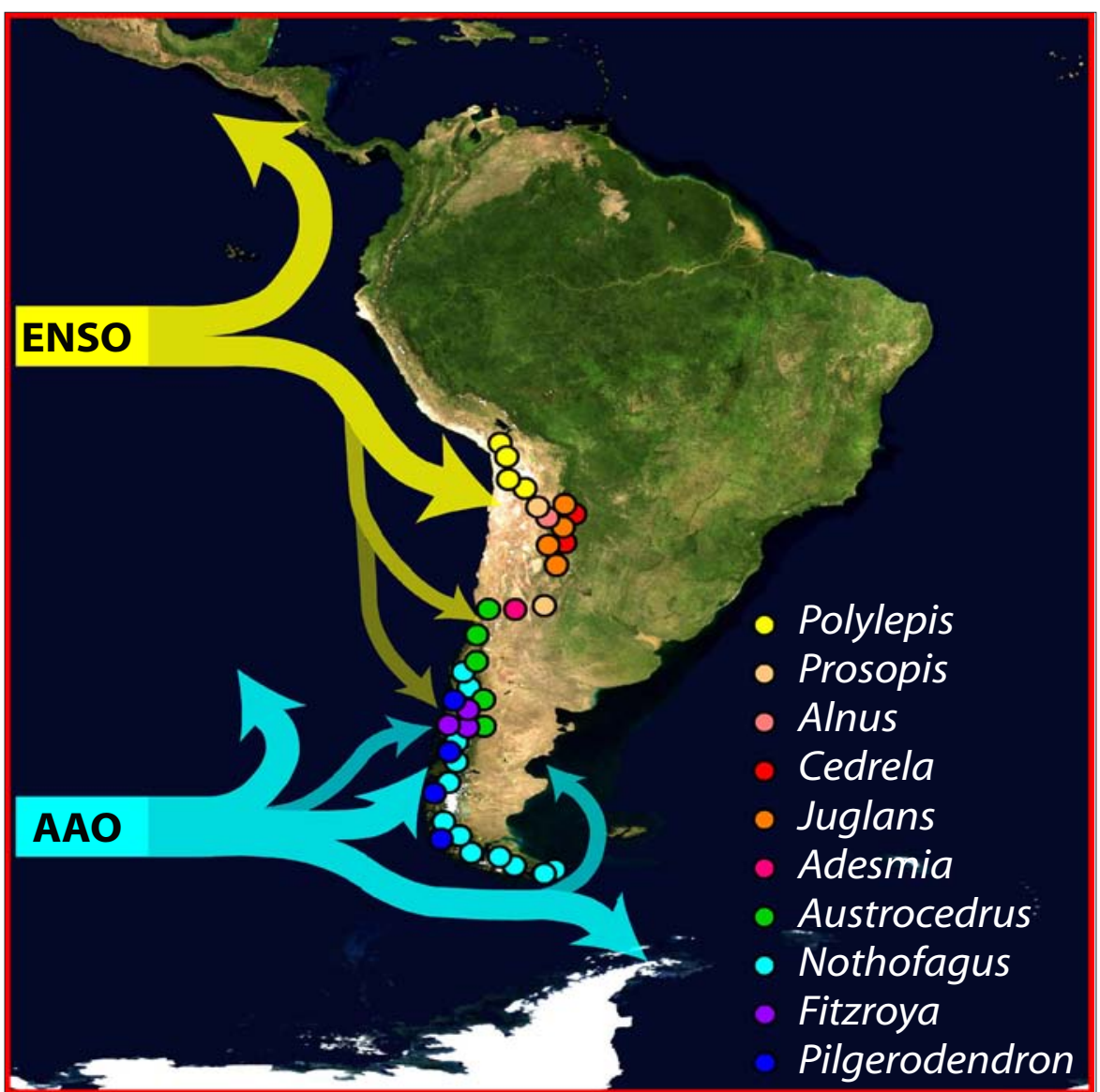

Figure 1: Tree-ring chronologies along the Andes Cordillera in South America. Major tree taxa used for developing the chronologies and their geographical distributions are shown. The geographical domain of the dominant tropical and extratropical forcings of regional climate variability across the Andes, as represented by the El Niño-Southern Oscillation (ENSO) and the Antarctic Oscillation (AAO), respectively, are also indicated. 